FE750

IFAS Extension

\title{
A Cornerstone of Alachua County's Economy and Land Base: The Economic Impact of Agriculture and Natural Resources $^{1}$
}

Rodney L. Clouser and Mohammad Rahmani

\section{INTRODUCTION}

This report provides a profile of agriculture and natural resource industries and an overview of their economic impacts in Alachua County, Florida. The report is based on data from the IMPLAN Pro database for Florida counties for 2006, data from the 2002 Census of Agriculture and data from reports by the Alachua County Property Appraiser. The format, structure, and wording for this report copies extensively from a guide developed by Rahmani, Hodges, and Mulkey to report economic impacts.

The IMPLAN Pro Economic Impact and Social Accounting software package, licensed to the University of Florida by the Minnesota IMPLAN Group, Inc., was used to generate multipliers for total industry output, total value added, total exports, total output impacts, and total value added impacts for each agricultural and natural resource sector of the economy to allow a more comprehensive assessment of impacts. In addition to direct sales of the industries in question, IMPLAN multipliers capture inter-industry purchases (indirect effects) and employee household spending (induced effects). No attempt was made to adjust for particular local conditions, and the analysis focused only on economic impacts resulting from operating revenues and employment created by agricultural and natural resource industries. All economic impacts generated from IMPLAN are reported in 2006 U.S. dollars.

\footnotetext{
${ }^{1}$ This is EDIS document FE750, a publication of the Food and Resource Economics Department, Florida Cooperative Extension Service, Institute of Food and Agricultural Sciences, University of Florida, Gainesville, FL. Published September 2008. Please visit the EDIS website at http://edis.ifas.ufl.edu.

${ }^{2}$ Rodney L. Clouser, professor and extension public policy specialist, and Mohammad Rahmani, coordinator of economic analysis, Food and Resource Economics Department, Florida Cooperative Extension Service, Institute of Food and Agricultural Sciences, University of Florida, Gainesville, FL.
}

The Institute of Food and Agricultural Sciences (IFAS) is an Equal Opportunity Institution authorized to provide research, educational information, and other services only to individuals and institutions that function with non-discrimination with respect to race, creed, color, religion, age, disability, sex, sexual orientation, marital status, national origin, political opinions, or affiliations. U.S. Department of Agriculture, Cooperative Extension Service, University of Florida, IFAS, Florida A\&M University Cooperative Extension Program, and Boards of County Commissioners. Larry Arrington, Dean. 
Data from the 2002 Census of Agriculture, the Alachua County Property Appraiser's Office and the State Department of Revenue were used to augment the economic impact analysis and to allow for a detailed description of agricultural and natural resource industries in Alachua County. The 2002 Census of Agriculture, conducted by the National Agricultural Statistics Service of the U.S. Department of Agriculture (USDA), provides information at the county level on farm numbers; land use; operator characteristics; the market values of land, buildings, and machinery; crop and livestock sales; farm expenses; and income from federal programs. A more recent Census of Agriculture was conducted in 2007, but data collected by USDA for Florida and Alachua County from that survey have not been publically reported and are not expected to be available for several months.

For informational purposes, a brief summary of the organization and definition of the agriculture and natural resource industry group in this report is provided. The early focus of the report is on production agriculture. This includes crops, all types of livestock, and forestry production in Alachua County. The focus then expands to a broader group of industry sectors. Included as part of the agriculture and natural resource group are agricultural inputs and services (veterinary, fertilizer, pest control, etc.), food and kindred products manufacturing (fruit and vegetable canning, bread and bakery products, seafood product preparation and packaging, etc.), forest products manufacturing (truss manufacturing, wood pallet manufacturing, etc.), and mining (stone, sand, gravel, etc.). However, nature-based recreation (golf, fishing, trapping, etc.) and food and kindred product distribution (food services, wholesale trade of food products, food and beverage stores, building materials and garden supplies, etc.) are not included as agriculture and natural resource industry sectors presented in this report.

\section{ALACHUA COUNTY AGRICULTURE: A SNAPSHOT}

According to the Census of Agriculture, in 2002, Alachua County agriculture can be summarized as follows (note how a farm is defined by the Census of Agriculture). Farms are "any place from which $\$ 1,000$ or more of agricultural products were produced and sold, or normally would have been sold, during the census year.” This definition was first used for the 1974 Census of Agriculture and has remained consistent since so that data are comparable across time periods since 1974. More detailed information on Alachua County agriculture is presented in Tables 1-8.

\section{Farm Numbers}

There were more than 1,493 farms in Alachua County (Table 1). Beef cattle ranching and farming comprise the largest number of farms (619), or more than 41 percent of all farms. Fruit and tree nuts ranked second (157 farms) and Nursery and greenhouse ranked third (118 farms). In total these three farm enterprises account for about 60 percent of all farms in the county.

\section{Farm Size Distribution}

The 1,493 farms identified in the Census consisted of 222,728 acres of land. The majority of farms were less than 100 acres (1,146 farms) and these farms totaled just over 31,100 acres. There were a total of 274 farms between 100 and 499 acres with total acreage for this size of operation at 55,343 acres. There were 73 farms of 500 acres or larger with a total acreage of 
136,213. Farms less than 100 acres accounted for 77 percent of total farms and 14 percent of acreage. Farms between 100 and 499 acres represented 18 percent of total farms and about 25 percent of the total acreage. Farms over 500 acres represented 5 percent of total farms and 61 percent of total acreage. Farms greater than 500 acres are relatively small in number but dominate in acreage.

\section{Market Value of Agricultural Products Sold and Net Farm Cash Income}

Table 4 reports the market value of agricultural products (all crops and livestock) sold in Alachua County. According to the 2002 Census of Agriculture, "market value of agricultural products sold represents the gross market value before taxes and production expenses of all agricultural products sold or removed from the place in 2002 regardless of who received the payment." Market value is equivalent to total sales, but does not include payments received for participation in other federal farm programs nor income from farm-related sources such as custom-work, other agricultural services, or income from non-farm sources.

The total market value of agricultural products sold in Alachua County was \$58.7 million in 2002 (Table 4). This represents an average market value of $\$ 39,293$ per farm. The total market value was 14 percent higher than in 1997 and on a per farm basis was 9 percent higher than the 1997 Census.

\section{Net Farm Cash Income}

Net farm cash income in the county from agricultural production in 2002 was estimated in the Census at $\$ 3.14$ million. This implies gross farm income from agriculture in the county is in the range of $\$ 64.5$ million. This represents a relatively thin margin of income exceeding expenses.

\section{Value of Agricultural Products by Commodity Group}

Crops, including nursery and greenhouse production, account for 64 percent of agricultural sales in Alachua County (\$37.6 million). Livestock, including poultry and dairy production and their products, represent the other 36 percent of sales. It should be noted that timber sales are not reported by the Census of Agriculture because they are not considered part of the agricultural industry by the North American Industry Classification system. This will be discussed later in more detail. The largest individual sector in terms of sales is vegetables, melons, and potato with reported sales of $\$ 12.9$ million. This is followed by the nursery, greenhouse, floriculture, and sod sector with sales of $\$ 11.1$ million and the cattle and calves sector with $\$ 9.4$ million.

\section{Farm Operator and Farm Organization Characteristics}

There are 2,252 farm operators in Alachua County. These operators represent nine-tenths (0.9) of one percent of the county's total population. About 32 percent of the operators consider agriculture (farming) as their primary occupation. The remainder of the operators (68 percent) considers something other than farming as their primary occupation. The vast major of the farms in Alachua County (about 91 percent) are organized as individual or family farm businesses. 
Individuals interested in more detail about Alachua County agriculture based on data from the 2002 Census of Agriculture should review the information presented in Tables 1-8.

\section{OTHER IMPORTANT AGRICULTURE AND NATURAL RESOURCE DATA}

While Census of Agriculture data is helpful in understanding the industry it is not the sole source of information and has certain short-comings. As presented earlier, the timber land sales sector is not reported in the Census because the North American Industry Classification system does not classify it as part of the agricultural sector. It needs to be noted that the Census data are selfreported by the producer or landowner and that other data may be available from professional sources that provide reliable information.

\section{Land Use Information}

Census of Agriculture data reported 222,728 acres of land in agriculture in Alachua County based on the Census definition of a farm and with the knowledge that land in timber is not fully reported. A more reliable source of information for land use is often available from local property appraiser's offices. Information presented here is from the Alachua County Property Appraiser's Office and is based on the 2007 preliminary property tax roll. This information reveals there were 7,404 parcels with agricultural use in Alachua County. These parcels totaled 341,536 acres in 2007 and represented about 55 percent of Alachua County's land base. This is down about 8 percent from 2002 when 371,752 acres were reported on 7,416 parcels. The number of parcels and the decline in acreage is consistent over the five-year period and is a more accurate representation of land in agriculture and natural resource use in the county.

\section{Land Value Information}

Data from the State Department of Revenue collected from the County Property Appraiser's Office indicates the market or just market value of agricultural land in Alachua County in 2006 was valued at \$861.3 million. This equates to a per acre value of about \$2500 per acre. However, agricultural land in Florida is taxed at its use value. That value in Alachua County in 2006 was reported as $\$ 97.3$ million, or about 11 percent of market value.

\section{Property Tax Payments}

Property tax payments in Alachua County vary based on taxes levied by various units of government, including special districts. In 2006, it is estimated the millage rate paid by Alachua County property owners varied between 20 and 24 mills (tax rate per \$1000 dollars of value). This calculates to a property tax payment on agricultural lands in the county that is estimated to range between $\$ 1.95$ and $\$ 2.3$ million.

\section{ECONOMIC IMPACT RESULTS}

As noted earlier, the IMPLAN software package and associated databases allow the estimation of multipliers to capture the total economic impact of agricultural and natural resource industries within the local economy. This section reports the results of impact estimations for Alachua 
County. Estimates are based only on the IMPLAN data set with no attempt to adjust for particular local situations. For each measure, the impacts reported include the direct impacts of output of the agricultural sector in question, the indirect impacts associated with inter-industry purchases of inputs by agriculture and its supplying industries, and the induced impacts of spending by employees and owners of agricultural and supplying industries.

Reported impacts include activities within production agriculture, natural resource industries (forestry, mining, and fishing), food and forest products manufacturing, agricultural input supply, and agricultural services.

Table 9 presents estimates of economic impacts for Alachua County's agriculture and natural resource industries. Additional detail for specific agriculture and natural resource industry groups are presented in Table 10.

- Total industry output for all agricultural and natural resource industries was \$390 million dollars in the county. In economic terms, the agriculture and natural resource industries accounted for 2.8 percent of the county's total output.

- Total value added to production for agriculture and natural resource industries was \$155 million. This represents 1.8 percent of the total value added by Alachua County industry groups.

- Total exports from Alachua County’s agriculture and natural resource based industries were $\$ 267$ million. This represents 6.1 percent of the total exports by all industry in Alachua County

The total output impacts for agriculture and natural resource industries in Alachua County were estimated at \$592 million. This represents 3.3 percent of total industry output for all sectors of Alachua County's economy. The largest total output impacts were from the following agriculture and natural resource industry groups:

Forestry, Wood and Paper Product Manufacturing

Food Product Manufacturing

Nursery and Greenhouse and Landscape Services

Agricultural Inputs and Services

Livestock \& Dairy Farming and Animal Products Manufacturing
\$132 million (M)

\$115.6 M

\$ $86.2 \mathrm{M}$

$\$ 72.9 \mathrm{M}$

$\$ 54.5 \mathrm{M}$

Total value-added impacts are the market value of a firm's output less the value of the inputs which it has purchased from others. It can be viewed as a net economic contribution by the industry sector after direct costs have been subtracted from gross sales. Value-added is the difference between the value of goods as they leave a particular stage of production and the costs of the goods as they entered that stage. Value-added includes payments made by industries to workers, interest, profits, and indirect business taxes. 
The total value-added impacts of agriculture and natural resource industries in Alachua County were \$280 million and represented 2.6 percent of the county’s total valued added impacts. Value added is a broad measure of economic contribution that is comparable to the Gross Domestic Product at the national level, and represents the net income created by an industry, or the difference between industry revenues and input purchases from other sectors; it includes personal and business net income, and capital consumption (Hodges 2008)

\section{CONCLUSION}

Agriculture and natural resource based industry is a large and diverse component of the Alachua County economy. Total industry output for all agricultural and natural resource industries was $\$ 390$ million dollars in the county. In economic terms, the agriculture and natural resource industries accounted for 2.8 percent of the county's total output. The total output impacts for agriculture and natural resource industries in Alachua County were estimated at \$592 million. This represents 3.3 percent of total industry output for all sectors of Alachua County's economy. The total value-added impacts of agriculture and natural resource industries in Alachua County were \$280 million and represented 2.6 percent of the county’s total valued added impacts.

What makes this more impressive is that this economic activity is generated from less than 1 percent of the county's population. The agriculture and natural resource sector also accounts for at least 55 percent of the land ownership and use in Alachua County. Over 90 percent of this land use is in individual and family farms. Property taxes from this land generates between $\$ 1.95$ to \$2.3 million dollars in tax revenue each year. Additionally, the land use generates other benefits such as water recharge, wildlife habitat, open space, locally grown food products, and scenic beauty. The agriculture and natural resource sector also generates more than 6 percent of export value of all Alachua County economic sectors. The implication of this export activity is that Alachua County agriculture and natural resource industries not only serve local markets, but regional and national markets as well. Without the contributions of the agriculture and natural resource sectors in Alachua County, a "major hole” would need to be filled in the county's economy and land use. 


\section{REFERENCES}

Alachua County Property Appraiser. 2008. Annual Report 2007. http://www.acpafl.org/annualreports.html (May).

Alachua County Property Appraiser. 2008. Annual Report 2002. http://www.acpafl.org/annualreports.html (May).

Florida Department of Revenue. 2008. 2006 Florida Property Valuations \& Tax Data. http://dor.myflorida.com/dor/property/06FLpropdata.pdf (May).

Hodges, Alan W., Mohammad Rahmani, and David Mulkey. 2008. Economic contributions of Florida agriculture, natural resources, food, and kindred product manufacturing and distribution, and service industries in 2006. Electronic Data Information Source (EDIS) FE702. Food and Resource Economics Department, University of Florida, Gainesville, FL (March).

Minnesota IMPLAN Group, Inc. 2006. IMPLAN System (data and software), Stillwater, MN. http://www.implan.com.

Rahmani, M., A.W. Hodges, and W.D. Mulkey. 2005. Profile and economic impacts of agriculture and natural resource industries in the south region of Florida. Electronic Data Information Source (EDIS) FE621. Food and Resource Economics Department, University of Florida, Gainesville, FL (December).

United States Department of Agriculture. 2004. 2002 Census Of Agriculture, Florida, State and County Data, Volume 1. Geographic Area Series, Part 9, AC-02-A-9, National Statistics Service, U.S. Department of Agriculture, Washington, D.C. (June). 
Source for Tables 1-8: 2002 Census of Agriculture, Florida, State and County data, Volume 1, Geographic area Series, Part 9, AC-02-A-9, Issued June 2004, National Statistics Service, U.S. Department of Agriculture.

Table 1. Farms by North American Industry Classification System: Alachua County, Florida, 2002

\begin{tabular}{|c|c|c|c|c|c|c|c|c|c|c|c|c|c|c|}
\hline $\begin{array}{l}\text { Total } \\
\text { farms }\end{array}$ & $\begin{array}{c}\text { Oilseed } \\
\text { and grain } \\
\text { farming }\end{array}$ & $\begin{array}{c}\text { Vegetable } \\
\text { and melon } \\
\text { farming }\end{array}$ & $\begin{array}{c}\text { Fruit and } \\
\text { tree nut } \\
\text { farming }\end{array}$ & $\begin{array}{l}\text { Greenhouse, } \\
\text { nursery, and } \\
\text { floriculture }\end{array}$ & $\begin{array}{c}\text { Other } \\
\text { crop } \\
\text { farming }\end{array}$ & $\begin{array}{l}\text { Tobacco } \\
\text { farming }\end{array}$ & $\begin{array}{c}\text { Cotton } \\
\text { farming }\end{array}$ & $\begin{array}{l}\text { Sugarcane, } \\
\text { hay, and } \\
\text { other crop }\end{array}$ & $\begin{array}{c}\text { Beef cattle } \\
\text { ranching } \\
\text { and } \\
\text { farming }\end{array}$ & $\begin{array}{c}\text { Dairy } \\
\text { cattle and } \\
\text { milk } \\
\text { production }\end{array}$ & $\begin{array}{c}\text { Hog and } \\
\text { pig } \\
\text { farming }\end{array}$ & $\begin{array}{c}\text { Poultry } \\
\text { and egg } \\
\text { production }\end{array}$ & $\begin{array}{c}\text { Sheep and } \\
\text { goat } \\
\text { farming }\end{array}$ & $\begin{array}{l}\text { Animal } \\
\text { aquaculture and } \\
\text { other animal } \\
\text { production }\end{array}$ \\
\hline & (1111) & (1112) & (1113) & (1114) & (1119) & (11191) & (11192) & $\begin{array}{l}11193, \\
11194, \\
11199)\end{array}$ & (112111) & (11212) & (1122) & (1123) & (1124) & $(1125,1129)$ \\
\hline 1,493 & 12 & 87 & 157 & 118 & 108 & 10 & - & 98 & 619 & 17 & 38 & 8 & 41 & 288 \\
\hline
\end{tabular}

Table 2. Farm Size Distribution, and Investment in Land \& Building, Machinery: Alachua County, Florida, 2002 and percent change $1997-2002$

\begin{tabular}{|c|c|c|c|c|c|c|c|c|c|c|c|c|c|c|c|}
\hline \multicolumn{4}{|c|}{ Farms } & \multicolumn{2}{|c|}{$\begin{array}{l}\text { Average size } \\
\text { of farm }\end{array}$} & \multicolumn{2}{|c|}{$\begin{array}{l}\text { Farms Less } \\
\text { than } 100 \text { acres }\end{array}$} & \multicolumn{2}{|c|}{$\begin{array}{l}\text { Farms } 100 \\
\text { to } 499 \text { acres }\end{array}$} & \multicolumn{2}{|c|}{$\begin{array}{l}\text { Farms } 500 \text { acres } \\
\quad \text { or more }\end{array}$} & \multicolumn{3}{|c|}{$\begin{array}{l}\text { Estimated asset value } \\
\text { of land and buildings }\end{array}$} & \multirow{2}{*}{$\begin{array}{c}\text { Estimated asset } \\
\text { value, machinery } \\
\text { \& equipment }\end{array}$} \\
\hline (Number) & (\% chg) & (Acres) & $\begin{array}{l}\text { (\% } \\
\text { chg) }\end{array}$ & $\begin{array}{l}\text { (Acre/ } \\
\text { farm) }\end{array}$ & (\% chg) & (Number) & (Acres) & (Number) & (Acres) & (Number) & (Acres) & (\$1000) (\% chg) & $(\$ /$ farm $)$ & (\$/acre) & \\
\hline 1,493 & 4 & 222,728 & 9 & 149 & 5 & 1,146 & 31,172 & 274 & 55,343 & 73 & 136,213 & 726,734 & 486,109 & 3,222 & 23,887 \\
\hline
\end{tabular}

Table 3A. Farm Land Use: Alachua County, Florida, 2002 and percent change 1997- 2002

\begin{tabular}{cc|cc|c|cc|c|c}
\hline All cropland & Harvested cropland & $\begin{array}{c}\text { Cropland used only for } \\
\text { pasture or grazing }\end{array}$ & $\begin{array}{c}\text { Cropland in cultivated } \\
\text { summer fallow }\end{array}$ & $\begin{array}{c}\text { Nursery, Greenhouse, } \\
\text { Floriculture (1), Under } \\
\text { glass or other protection }\end{array}$ & $\begin{array}{c}\text { Nursery, Greenhouse, } \\
\text { Floriculture(1), } \\
\text { In the open }\end{array}$ \\
\hline (Acres) $\quad(\%$ chg) & (Acres) & (\% chg) & (Acres) & $(\%$ chg) & (Acres) & $(\%$ chg) & (Sq. ft.) & (Acres) \\
\hline 80,269 & 10 & 39,281 & 28 & 6,446 & -15 & 441 & -14 & 511,580 \\
\hline
\end{tabular}

(1) Aquatic Plants, Mushrooms, Flower \& Vegetable seeds and Sod Harvested 
Table 3B. Farm Land Use: Alachua County, Florida, 2002 and percent change 1997- 2002

\begin{tabular}{|c|c|c|c|c|c|c|c|c|c|c|c|c|c|}
\hline \multicolumn{2}{|c|}{$\begin{array}{c}\text { Pasture and } \\
\text { rangeland, other } \\
\text { than cropland \& } \\
\text { woodland pastured }\end{array}$} & \multicolumn{2}{|c|}{$\begin{array}{l}\text { Pastureland, all } \\
\text { types }\end{array}$} & \multicolumn{2}{|c|}{ Woodland } & \multicolumn{2}{|c|}{$\begin{array}{l}\text { Woodland } \\
\text { pastured }\end{array}$} & \multicolumn{2}{|c|}{$\begin{array}{l}\text { Woodland not } \\
\text { pastured }\end{array}$} & \multicolumn{2}{|c|}{$\begin{array}{c}\text { Land in } \\
\text { Conservation or } \\
\text { Wetlands Reserve } \\
\text { Programs }\end{array}$} & \multirow{2}{*}{$\begin{array}{c}\begin{array}{c}\text { Certified } \\
\text { organically } \\
\text { produced crop } \\
\text { lands }\end{array} \\
\text { (Acres) }\end{array}$} & \multirow{2}{*}{$\begin{array}{c}\begin{array}{c}\text { Land enrolled in } \\
\text { federal or other } \\
\text { crop insurance } \\
\text { programs }\end{array} \\
\text { (Acres) }\end{array}$} \\
\hline (Acres) & (\% chg) & (Acres) & (\% chg) & (Acres) & (\% chg) & (Acres) & (\% chg) & (Acres) & (\% chg) & (Acres) & (\% chg) & & \\
\hline 86,289 & 25 & 145,229 & 11 & 44,207 & -15 & 24,398 & -9 & 19,809 & -21 & 1,726 & -50 & 135 & 9,025 \\
\hline
\end{tabular}

Table 4. Market Value of Agricultural Products Sold, Value of Government Payments, Production Expenses, and Net Farm Cash income from Operation: Alachua County, Florida, 2002 and percent change 1997- 2002

\begin{tabular}{cccc|c|cc|cc}
\hline \multicolumn{2}{|c|}{ Market value of all agricultural products sold } & $\begin{array}{c}\text { Value of } \\
\text { government } \\
\text { payments }\end{array}$ & $\begin{array}{c}\text { Total farm production } \\
\text { expenses }\end{array}$ & \multicolumn{2}{c}{$\begin{array}{c}\text { Net farm cash income from } \\
\text { operation }\end{array}$} \\
\hline$(\$ 1000)$ & $(\% \mathrm{chg})$ & $(\$ / \mathrm{farm})$ & $(\% \mathrm{chg})$ & $(\$ 1000)$ & $(\$ 1000)$ & $(\$ /$ farm $)$ & $(\$ 1000)$ & $(\$ /$ farm $)$ \\
\hline 58,665 & 14 & 39,293 & 9 & 567 & 61,274 & 40,986 & 3,141 & 2,101 \\
\hline
\end{tabular}

Table 5. Value of Agricultural Products by Commodity Group: Alachua County, Florida, 2002 and percent change 1997- 2002

\begin{tabular}{|c|c|c|c|c|c|c|c|c|c|c|c|c|c|}
\hline $\begin{array}{c}\text { Market value } \\
\text { of all } \\
\text { Livestock \& } \\
\text { Poultry) } \\
\text { agricultural } \\
\text { products sold }\end{array}$ & \begin{tabular}{|c|} 
All crop \\
Including nursery \\
and greenhouse
\end{tabular} & $\begin{array}{c}\text { Vegetables, } \\
\text { melons, } \\
\text { potatoes, \& } \\
\text { sweet } \\
\text { potatoes }\end{array}$ & $\begin{array}{c}\text { Fruits, tree nuts, } \\
\text { and berries }\end{array}$ & $\begin{array}{l}\text { Nursery, } \\
\text { greenhouse, } \\
\text { floriculture, } \\
\text { \& sod }\end{array}$ & \begin{tabular}{|c|} 
Other \\
crops \\
and hay
\end{tabular} & $\begin{array}{l}\text { Livestock, poultry, } \\
\text { and their products }\end{array}$ & Poultry and eggs) & Cattle and calves & $\begin{array}{l}\text { Milk and other } \\
\text { dairy products } \\
\text { from cows }\end{array}$ & Hogs and pigs & $\begin{array}{c}\text { Sheep, } \\
\text { goats, and } \\
\text { their } \\
\text { products }\end{array}$ & $\begin{array}{l}\text { Horses, } \\
\text { ponies, } \\
\text { mules, } \\
\text { burros, \& } \\
\text { donkeys }\end{array}$ & $\begin{array}{c}\text { Aquacul- } \\
\text { ture }\end{array}$ \\
\hline$(\$ 1000)$ & (\$1000) (\% chg) & $(\$ 1000)$ & (\$1000) (\% chg) & $(\$ 1000)$ & $(\$ 1000)$ & (\$1000) (\% chg) & $(\$ 1000)$ (\% chg) & $(\$ 1000)$ (\% chg) & (\$1000) (\% chg) & (\$1000) (\% chg) & $(\$ 1000)$ & $(\$ 1000)$ & $(\$ 1000)$ \\
\hline 58,665 & $37,620 \quad 17$ & 12,859 & $8,113 \quad 290$ & 11,122 & 2,748 & 21,044 & & $9,402 \quad 10$ & $5,579 \quad-32$ & -76 & 76 & 878 & 183 \\
\hline
\end{tabular}


Table 6. Characteristics of Principal Operator, and Primary Occupation of Farmers: Alachua County, Florida, 2002 and percent change 1997-2002

\begin{tabular}{|c|c|c|c|c|c|c|c|c|c|}
\hline \multirow{2}{*}{$\begin{array}{c}\text { Total operators } \\
\text { (Number) }\end{array}$} & \multirow{2}{*}{$\begin{array}{c}\begin{array}{c}\text { Total women } \\
\text { operators }\end{array} \\
\text { (Number) }\end{array}$} & \multicolumn{2}{|c|}{$\begin{array}{l}\text { Primary occupation: } \\
\text { Farming }\end{array}$} & \multicolumn{2}{|c|}{ Primary occupation: Other } & \multicolumn{4}{|c|}{ Female farms } \\
\hline & & (Number) & (\% chg) & (Number) & (\% chg) & (Number) & (\% chg) & (Acres) & (\% chg) \\
\hline 2,252 & 819 & 728 & 36 & 765 & -15 & 359 & 38 & 26,358 & 83 \\
\hline
\end{tabular}

Table 7. Type of Business Organization: Alachua County, Florida, 2002 and percent change 1997- 2002

\begin{tabular}{|c|c|c|c|c|}
\hline Family or individual farms & Partnership farms & Corporation: Family-held farms & $\begin{array}{c}\text { Corporation: Other than family } \\
\text { held farms }\end{array}$ & $\begin{array}{l}\text { Other-cooperative, estate or } \\
\text { trust, institutional, etc. }\end{array}$ \\
\hline (Number) (\% chg) (Acres) (\% chg) & (Number) (\% chg) (Acres) (\% chg) & \begin{tabular}{|lll} 
(Number) (\% chg) & (Acres) & (\% chg)
\end{tabular} & \begin{tabular}{|lll} 
(Number) & (\% chg) & (Acres)
\end{tabular} & $\begin{array}{lll}\text { (Number) } & \text { (\% chg) (Acres) }\end{array}$ \\
\hline $148,139 \quad 39$ & $\begin{array}{lll}-18 & 25,483 & -29\end{array}$ & 40,874 & 3,656 & 4,576 \\
\hline
\end{tabular}

Table 8. Ethnicity of Farm Operators: Alachua County, Florida, 2002

\begin{tabular}{|c|c|c|c|c|c|c|c|c|c|c|}
\hline \multicolumn{3}{|c|}{ White } & \multicolumn{2}{|c|}{ Black or African American } & \multicolumn{3}{|c|}{$\begin{array}{c}\text { Spanish, Hispanic, or Latino } \\
\text { Origin } \\
\end{array}$} & \multicolumn{3}{|c|}{ Other ethnic groups * } \\
\hline $\begin{array}{c}\text { (Farm } \\
\text { Numbers) }\end{array}$ & $\begin{array}{l}\text { (Operator } \\
\text { Number) }\end{array}$ & (Acres) & $\begin{array}{l}\text { (Farm } \\
\text { Number } \\
\text { ) }\end{array}$ & $\begin{array}{l}\text { (Operator (Acres) } \\
\text { Number) }\end{array}$ & $\begin{array}{c}\text { (Farm } \\
\text { Number) }\end{array}$ & $\begin{array}{l}\text { (Operator } \\
\text { Number) }\end{array}$ & (Acres) & $\begin{array}{c}\text { (Farm } \\
\text { Number) }\end{array}$ & $\begin{array}{l}\text { (Operator } \\
\text { Number) }\end{array}$ & (Acres) \\
\hline 1,365 & 1,983 & 211,166 & 127 & 11,932 & 57 & 70 & 7,019 & 39 & 43 & 2,580 \\
\hline
\end{tabular}


Table 9. Alachua County, Florida, Economic Impacts, Industry Groups, 2006 Data

\begin{tabular}{|c|c|c|c|c|c|}
\hline Industry Groups & $\begin{array}{c}\text { Total } \\
\text { Industry } \\
\text { Output } \\
\text { (\$M) }\end{array}$ & $\begin{array}{c}\text { Total } \\
\text { Value } \\
\text { Added } \\
(\$ M)\end{array}$ & $\begin{array}{c}\text { Total } \\
\text { Exports } \\
\text { (\$M) }\end{array}$ & $\begin{array}{c}\text { Total } \\
\text { Output } \\
\text { Impacts } \\
(\$ M)\end{array}$ & $\begin{array}{c}\text { Total } \\
\text { Value } \\
\text { Added } \\
\text { Impacts } \\
\text { (\$M) }\end{array}$ \\
\hline $\begin{array}{l}\text { Agriculture, Natural Resources, Related } \\
\text { Manufacturing \& Services }\end{array}$ & 390 & 155 & 267 & 592 & 280 \\
\hline Construction & 982 & 390 & 16 & 998 & 400 \\
\hline Consumer Services & 339 & 163 & 83 & 421 & 216 \\
\hline Education & 1,834 & 1,789 & 100 & 1,942 & 1,858 \\
\hline Government & 688 & 609 & 8 & 695 & 613 \\
\hline Health Care & 1,869 & 1,059 & 1,181 & 3,059 & 1,817 \\
\hline Information and Communications & 516 & 240 & 197 & 714 & 364 \\
\hline Manufacturing & 1,292 & 377 & 930 & 1,849 & 719 \\
\hline Miscellaneous Residual Accounts & -5 & -5 & 113 & -5 & -5 \\
\hline Private Households & 720 & 644 & 0 & 720 & 644 \\
\hline Professional and Technical Services & 1,156 & 611 & 276 & 1,468 & 807 \\
\hline Real Estate and Financial Services & 1,448 & 819 & 372 & 1,861 & 1,102 \\
\hline Retail Trade & 921 & 588 & 133 & 1,066 & 685 \\
\hline Social Services \& Organizations & 199 & 94 & 91 & 289 & 151 \\
\hline Transportation & 283 & 182 & 129 & 405 & 261 \\
\hline Travel, Food and Entertainment Services & 697 & 350 & 280 & 956 & 519 \\
\hline Utilities & 292 & 110 & 133 & 332 & 137 \\
\hline Wholesale Trade & 425 & 287 & 36 & 463 & 312 \\
\hline Grand Total & 14,046 & 8,462 & 4,346 & 17,823 & 10,880 \\
\hline
\end{tabular}

Source: IMPLAN Professional Data, Minnesota IMPLAN group Inc., Stillwater, Minnesota 55082 
Table 10. Alachua County, Florida, Economic Impacts, Agriculture and Natural Resources Industry Group, 2006 Data

\begin{tabular}{|c|c|c|c|c|c|}
\hline $\begin{array}{l}\text { Agriculture and Natural Resources Industry } \\
\text { Group }\end{array}$ & $\begin{array}{l}\text { Industry } \\
\text { Output } \\
\text { (\$M) }\end{array}$ & $\begin{array}{l}\text { Total } \\
\text { Value } \\
\text { Added } \\
(\$ \mathbf{M})\end{array}$ & $\begin{array}{l}\text { Total } \\
\text { Exports } \\
(\$ M)\end{array}$ & $\begin{array}{l}\text { Output } \\
\text { Impacts } \\
(\$ M)\end{array}$ & $\begin{array}{c}\text { Total } \\
\text { Value } \\
\text { Added } \\
\text { Impacts } \\
\text { (\$M) }\end{array}$ \\
\hline $\begin{array}{l}\text { Agricultural Inputs \& Services (fertilizers, } \\
\text { pesticides, veterinary, support activities, equipment } \\
\text { manufacturing) }\end{array}$ & 48.91 & 21.58 & 30.77 & 72.90 & 36.86 \\
\hline $\begin{array}{l}\text { Environmental Horticulture (nursery \& } \\
\text { greenhouse, landscape services) }\end{array}$ & 68.36 & 38.78 & 17.88 & 86.15 & 50.44 \\
\hline Forestry, Wood \& Paper Product Manufacturing & 88.82 & 33.28 & 62.61 & 132.19 & 60.84 \\
\hline Fruit \& Vegetable Farming \& Processing & 49.24 & 28.30 & 38.84 & 80.00 & 48.66 \\
\hline Grain \& Oilseed Farming \& Processing & 0.07 & 0.03 & 0.07 & 0.12 & 0.07 \\
\hline $\begin{array}{l}\text { Livestock \& Dairy Farming \& Animal Products } \\
\text { Manufacturing }\end{array}$ & 32.05 & 9.08 & 26.45 & 54.48 & 21.73 \\
\hline Mining & 10.12 & 5.60 & 10.48 & 17.25 & 10.28 \\
\hline Other Crop Farming & 9.79 & 5.05 & 7.80 & 15.80 & 9.04 \\
\hline Other Food Product Manufacturing & 71.53 & 10.72 & 64.04 & 115.62 & 35.74 \\
\hline Sugarcane Farming, Refined Sugar \& Confections & 4.96 & 0.27 & 4.79 & 7.90 & 2.07 \\
\hline Tobacco Farming \& Manufacturing & 1.75 & 1.59 & 1.71 & 3.47 & 2.75 \\
\hline Wildlife (hunting) & 0.00 & 0.00 & 0.00 & 0.00 & 0.00 \\
\hline Grand Total & 390.20 & 155.38 & 266.81 & 591.71 & 280.32 \\
\hline
\end{tabular}

Source: IMPLAN Professional Data, Minnesota IMPLAN group Inc., Stillwater, Minnesota 55082 